\title{
Representations of the Ideological Identity of Woman Characteristics in Commercial Advertisements
}

\author{
A.A. Sagung Diah Oka Yuniantari, I Wayan Budiarta, \& \\ I Gusti Ayu Agung Dian Susanthi \\ Postgraduated Program in Linguistic, Universitas Warmadewa \\ yuniantari94@gmail.com, budy4rt4@yahoo.com, gungdian03@gmail.com
}

\begin{tabular}{|c|}
\hline Published: 15/10/2021 \\
\hline How to cite (in APA style): \\
\hline $\begin{array}{l}\text { Yuniantari, A.A. S. D. O., Budiarta, I. W., \& Susanthi, I. G. A. A. D. (2021). Representations of the Ideological Identity of } \\
\text { Woman Characteristics in Commercial Advertisements. Retorika: Jurnal Ilmu Bahasa, 7(2), 115-120. doi: } \\
\text { https://doi.org/10.22225/jr.7.2.3294.115-120 }\end{array}$ \\
\hline
\end{tabular}

Abstract - Commercial advertisement is a form of communication with the intention of promoting the sale of a particular product attached to a brand. The main strength of advertisement lies in the language and word choice (verbal signs), images (visual signs) as well as their creativity which is made as attractive as possible and followed by trends or phenomena that exist in the world, one of them is a gender issue. In commercial ads, woman is often shown referring to certain stereotypes so this research object is an advertisement that features woman as the main model. This research aims to describe the signs found in ads, the meaning of the signs, and ideological identity of the woman. The theory used in this research is the theory of semiotic by Roland Barthes (1991) and the theory of ideology by John Storey (2004). The data source of this research is commercial advertisements that have been shown on television. In collecting the data, the writer used the documentation method, observation method, and note taking technique. The collected data are classified based on their verbal and visual signs first. Then the data were analyzed based on denotative meaning, connotative meaning, myth, and representations of the ideological identity of woman produced by signs. The results of the analysis were presented by using formal and informal methods. Based on the results of the analysis, in Kondom Sutra ads there are two verbal signs in the form of dialog spoken by a woman and a man and there are six visual signs that produced denotative meaning and connotative meaning. The representation of ideological identity of woman that produced in this ads is, woman imagine as sensuality person. It shows from her sexy clothes, facial expressions like beating her lips and body curve that are able to arouse passion of the audiences.

Keywords: Advertisement, Meaning, Ideology

\section{INTRODUCTION}

Language has an important role in human life because language is used to express information, ideas, message, emotion, or feelings, both in speaking or writing. Nowadays, language has a close relationship with mass media because the development of language is determined by the mass media. Mass media is a tool that is used to convey the message from the source to society. One of the mass media that is most often used by people is television, television combines audio and visual elements that have their appeal over the other mass media. Besides showing many programs, television is also used as a promotion tool in the form of commercial advertisement because television is an object that communicates with audiences. In other words, language is also used in a certain purposes such as promoting a brand product (Gaho, 2020). 
Advertising is one of the mechanisms used by modern industrial capitalism to organize and ensure markets for its goods (Dyer, 1983). The existence of advertisement in the mass media can't be separated from verbal and visual signs that support the advertisement, so it will produce a good illustration for the viewers. The main power of the advertisement lies in the language and word choice (verbal sign), images (visual sign), and its creativity which is made as attractive as possible and followed by trend or phenomenon to influence the audience to use the product or service. In our life many phenomena appear over time, one of them is gender issues. Gender marks a sociocultural distinction between men and women on the basis of the traits and behavior that are conventionally regarded as characteristic of and appropriate to the two groups of people (John, 1997). The phenomenon of gender issues is used by the advertiser to increase their creativity in making an attractive ads, in representing the advertisement there is an understanding of ideology which is assessed from gender perspective.

Advertisement usually used unique words and sometimes looks more exaggerated to influence the consumer to use the products but sometimes indirectly advertisement display gender issues about a woman and produced an ideology about the image of the woman. The ideology refers to an ideological form that aims to attract attention by using methods like those used in the text (including television advertisement) as mass media products to present certain images about the world (Storey, 2004). The ideology can be found from a representation, the representation can be found by looking for the meanings of signs in the image (visual) and sound (verbal). Barthes divides meaning into two, namely denotative meaning and connotative meaning. At the denotation level, language presents conventions or social codes that are explicit, namely the meaning codes of the sign immediately appear to the surface based on the relation between the signifier and the signified. Meanwhile, at the connotation level, language presents codes whose sign meanings are implicit, namely a code system whose signs contain hidden meanings (Barthes, 1991).

Many researchers have conducted research on gender issues, one of which is a study conducted by Nurnanengsi (2016). The results of the research are found the meaning of the concept of beauty in terms of clothing, namely the clothing used by the model is polite clothing as a Muslim identity giving a new beautiful concept that beauty doesn't have to be in clothes that show the body, meaning in terms of gesture through facial expressions and gestures showing a polite attitude in front her parents, meaning in terms of make-up, and meaning in terms of dialogue spoken by the main model with low intonation and soft pronunciation. The myth that appears in this ads is a beautiful concept from an educational perspective. In the past, women were underestimated for those who did not have a high level of education. This advertisement is here to give a message to Indonesian women that education for women is important in order to have same equality with men.

A similar research was also conducted by Dwi (2015). The result of this research found the ideological identity of women's beauty is found with the physical alignment of women. Advertisements create a similar pattern, a woman is said to be beautiful if she has long straight hair, white skin, smooth face, slim and flat stomach. It can be seen, the meaning of "beautiful" has become a standard and homogeneous thing. All over the world, women are said to be "beautiful" if they fit the aforementioned standards, beyond that they cannot be said to be beautiful.

The next research on gender issues carried out by Rahmawati (2010). In this research, the author discusses the influence of gender which is shown in one of the detergent advertisements where the results of her research are gender equality and gender imbalance. A form of gender equality is that women are able to do heavy work such as lifting gallons of water as a form of responsibility at home. While the gender imbalance is subordination, men have higher power than women in the household, this can be seen when the advertisement shows the figure of a housewife drying clothes while a father figure is reading a newspaper. Women are seen to be able to do heavy work that is usually done by men, but are still placed as housewives. In this study, there is an image that implies the ideology of housewives (housewifization) in some advertising representations solely as a reference for creating an idealized image of social relations. Women tend to be domesticated, namely as gender subjects who have big 
responsibilities and roles in household management.

Based on the explanation above, this research focuses on how the advertisement created meanings regarding gender issues, especially about a woman through tagging myths and ideologies. The object of this research is a commercial advertisement from various products and services that present a woman as a model. This research focused on the use of the ideological identity of women's characteristics in manipulating the meaning of the advertised product reality.

\section{METHODS}

This study used a qualitative approach because it produces descriptive data like written or spoken words from observable people, uses analysis, refers to the data, uses theories as supporting material. According to (Moleong, 2000) qualitative research is research that intends to understand the phenomenon that occurs on research subject for example behavior, perception, motivation, actions, etc, holistically and descriptively in the form of words and language in a special natural context and by using various natural methods.

The object of this research is a commercial advertisement from Kondom Sutra that present a woman as a model. These advertisements are obtained using documentation methods such as downloading the video via youtube. Documentation method is the method of collecting data in the form of writing, film/video, images, photos and so on relating with the discussion of the research. Other methods used are listening and notetaking methods. The listening method is a method that is done by listening to the language use (Sudaryanto, 1993). Besides listening to the language used in the advertisement, listening is also done on the visual elements of the advertisement where some actions or signs support the speech that is said by the model on the advertisement.

Meanwhile, a note-taking method is a method that is done by writing the speech in the advertisement. The data were classified according to their verbal and visual signs and then, analyzed their denotative and connotative meanings so that is found how the representation of the ideological identity of woman characteristics is produced. The results of the analysis were presented by using formal and informal methods. Presenting the result of analysis using informal methods is done by formulating in ordinary words. While the formal method is done by formulating using signs and symbols (Sudaryanto, 1993).

\section{RESULT ANDDISCUSSION}

This section describes the initial stages of the analysis. The data were analyzed based on the scope of problems that focused on how the signs and meanings that symbolize the ideological identity of woman and how the ideological identities of women's characteristics are generated from commercial advertisements.

The advertisement used is Kondom Sutra advertisement, quoted from Klikdokter.com, Kondom Sutra is contraceptives made from natural latex with thick sizes. Kondom Sutra advertisement is one of the vulgar advertisements shown on television and attracts the attention of viewers because there are sensual elements of the woman in the advertisement. The analysis in this section is carried out sequentially, namely explaining the verbal and visual signs found in ads, explaining the meanings of the signs, and the last explaining the ideological identity of the woman.

\section{Verbal Signs in Kondom Sutra Ads}

Dialogue :

Man : Masih mau lagi? (Still want more?)

Woman : Biar mainnya lebih lama (So we can play longer)

Man : Oke (Okay)

Woman : Uhhh

Hanya dengan Sutra oke, aksi jadi lebih lama, gaya apapun oke dan oke dan oke (dinarasikan dengan suara perempuan)

Only with Sutra Okay, the action is longer, whatever the position, it's OK, OK and OK! (narrated with woman voice)

Man : Masih mau lagi? (Still want more?)

Woman : Arghh

Sutra oke lebih lama lebih oke ! (dinarasikan dengan suara perempuan) 
Sutra OK, longer, better, more OK! (narrated with woman voice)

In that advertisement, there are two dialogues uttered by man and woman ideological identity of women's characteristics, characters where the dialogue reflects the the explanation is as follows:

Table 1. Verbal Signs in Kondom Sutra Ads

\begin{tabular}{|l|l|l|}
\hline \multicolumn{1}{|c|}{ Dialogue } & \multicolumn{1}{c|}{ Denotative } & \multicolumn{1}{c|}{ Connotative } \\
\hline $\begin{array}{l}\text { Masihmaulagi? } \\
\text { (Still want more?) }\end{array}$ & $\begin{array}{l}\text { A man asks a question to } \\
\text { the interlocutor }\end{array}$ & $\begin{array}{l}\text { The man offers to have } \\
\text { sex again }\end{array}$ \\
\hline $\begin{array}{l}\text { Biarmainnyalebih lama } \\
\text { (So we can play longer) }\end{array}$ & $\begin{array}{l}\text { A woman gives an } \\
\text { opinion to the } \\
\text { interlocutor }\end{array}$ & $\begin{array}{l}\text { These women expect } \\
\text { sex with a long } \\
\text { duration }\end{array}$ \\
\hline
\end{tabular}

\section{Visual Signs in Kondom Sutra Ads}

In this advertisement, there are six visual signs that reflect the ideological identity of women's characteristics, these are explained in the following table:

Table 2. Visual Signs in Kondom Sutra Ads

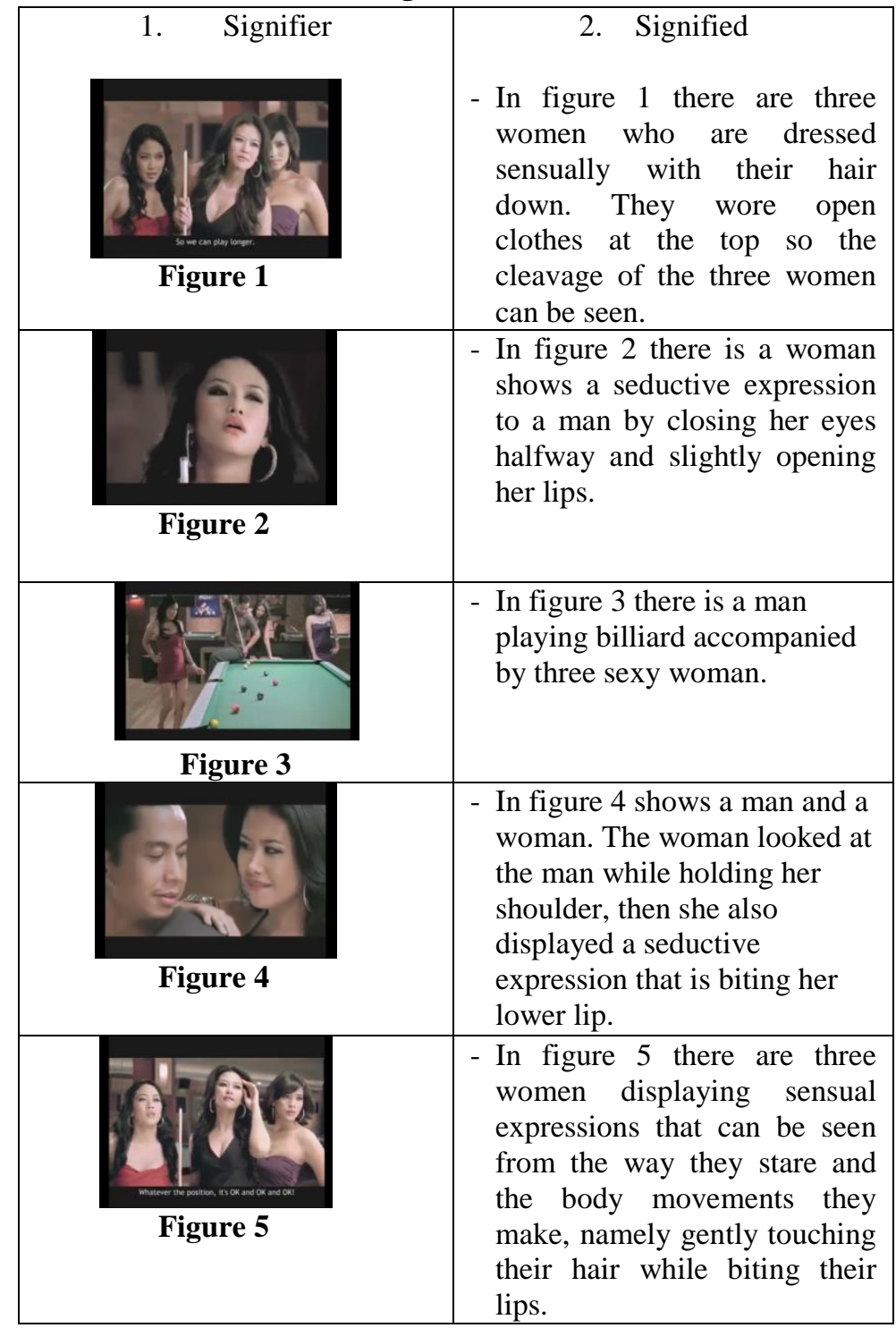




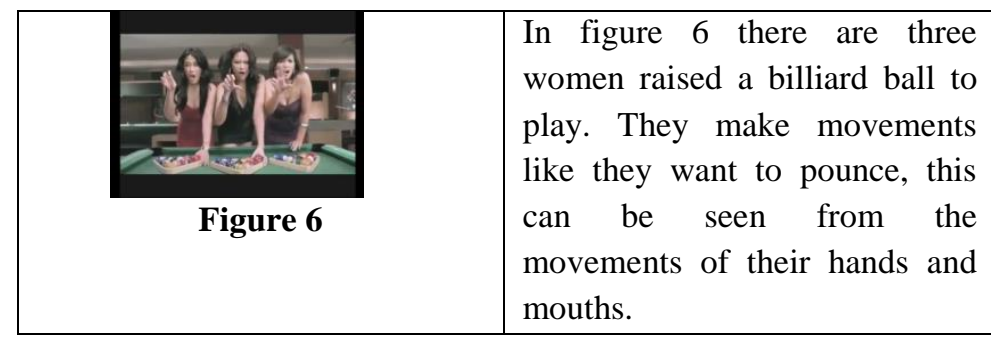

\begin{tabular}{|l|l|}
\hline $\begin{array}{l}\text { I. Sign } \\
\text { I SIGNIFIER }\end{array}$ & \multicolumn{1}{c|}{ II SIGNIFIED } \\
$\begin{array}{l}\text { There are three women in } \\
\text { sexy clothes seducing a } \\
\text { man who is playing } \\
\text { billiards }\end{array}$ & $\begin{array}{l}\text { The billiard game } \\
\text { between three women and } \\
\text { one man is connoted as a } \\
\text { sex }\end{array}$ \\
\hline \multicolumn{3}{|c|}{$\begin{array}{r}\text { III SIGN } \\
\text { Myth) }\end{array}$} \\
Women are more aggressive and like to flirt with men
\end{tabular}

\section{Ideological Identity of Woman}

Denotative meaning produced from visual signs is three women are wearing sexy clothes seducing a man who is playing billiard. Meanwhile, the connotative meaning is the billiard game between three woman and one man is connotated as sex. When viewed from visual perspective, the myth produced from these ads is, the woman looks more aggressive and likes to flirt man. It can be seen from the gestures displayed by three women to seduce the man. From here comes a representation of the ideological identity of woman characteristic such as woman is a sensual person. The emergence of this sensuality is presented by the female figure for the men. According to (Ida \& Surya, 2002), sensuality is displayed by attaching certain attributes to women, such as sexy clothes on certain body parts because advertisements are visual in nature, so they can arouse passion for the audience.

This advertisement emphasizes visual aspects of physic and all attributes attached to the female character, start from facial expression, body movement, and clothes. The image of the woman in this advertisement is built by manipulating the female body as a sign of symbols that are stereotypically inherent in women, such as sexiness, tenderness, indulgence and others. The existence of the value of women's sensuality in advertisements is still seen as a compulsory touch to make a product best seller, especially contraceptive products.

\section{CONCLUSION}

In Kondom Sutra advertisement there are two verbal signs in the form of dialogue spoken by a woman and a man, it produced denotative and connotative meaning. Then also found six visual signs in the form of images, which produced denotative and connotative meanings. This visual image generates the myth such as woman more aggressive than man and woman also flirting with man. The representation of the identity ideology of woman characteristic produced from the myth is, woman is a sensuality person. It can be seen from the sexy clothes, facial expressions, body curves that can arouse the passion of the audiences.

The appearance of this sensuality is presented by the female figure for the benefit of men. Sensuality is shown by attaching certain attributes to women, such as minimal or revealing clothes on certain body parts because advertising is visual, so it can arouse passion for the audience.

\section{REFERENCES}

Ahlina, R. N. (2019). Representasi Cantik Dalam WEBTOON (Analisis Semiotika Roland Barthes Terhadap Webtoon I am Gangnam Beauty). Universitas Lampung.

Aprilia, D. R. (2005). Iklan dan Budaya Popular: Pembentukan Identitas Ideologis Kecantikan Perempuan oleh Iklan (Analisis Semiotika Iklan Cetak WRP Body Shape \& Prolene). Jurnal Ilmu Komunikasi, 2(1), 41-65.

Barthes, R. (1991). Mythologies. Paris: Jonathan Cape Ltd. 
Caplan, P. J., Crawford, M., Hyde, J. S., \& Richardson, J. T. E. (1997). Gender Differences in Human Cognition. Oxford.

Dyer, G. (1983). Advertising as Communication. England: Clays Ltd.

Gaho, R. (2020). What's up with Vocabulary and Grammatical Use in News Texts? Konferensi Tahunan Atma Jaya, 325-331.

Hall, S. (2003). Cultural Representations and Signifying Practice. Great Britain :Bath Press Colourbooks.

Halliday, M. A., \& Hasan. (1989). Language, Context, and Text: Aspect of Language in A Social-Semiotic Perspective. Victoria: Deakin University.

Hartanto, R. (2016). Mengkaji Relasi Agama dan Ideologi. DINIKA Academic Journal of Islamic Studies, 1(1).

Ida, R., \& Surya, Y. I. (2002). Politik Tubuh Dan Sensualitas Perempuan: Diskursus Media Terhadap Fenomena Goyang Penyanyi Dangdut Perempuan. Universitas Airlangga.

Masrukhi. (2016). Iklan Komersial Media Cetak: TinjauanTeks dan Konteks. Jurnal Studi Timur Tengah, 9(2).

Monro, S. (2007). Transmuting Gender Binaries: the Theoretical Challenge. Sociological Research Online, 12(1).

Moleong, L. (2000). Qualitative Research Methods. PT Remaja Rosdakarya.
Mubaligh, A. (2010). Relasi Bahasa dan Ideologi. Lingua, 5(2), 112-118.

Nugrahani, F. (2014). Metode Penelitian Kualitatif dalam Penelitian Pendidikan Bahasa. Surakarta.

Nurhaini, E. R. (2016). Konstruksi Identitas Diri Blogger pada Blog tentang Kepustakawanan, 5(3), 1-13.

Nurnanengsi. (2016). Representasi Konsep Cantik dalam Iklan Televisi (Analisis Semiotika dalam Iklan Pelembab Wajah Fair \& Lovely Versi Gita Virga). Universitas Islam Negeri.

Oktaviani, K. (2017). Representasi Diskriminasi Perempuan Dalam Meme Bertema Perempuan. Surabaya.

Rahmawati, A. S., Tripambudi, S., \& Lestari, P. (2010). Bias Gender dalam Iklan Attack Easy di Televisi. Jurnal Ilmu Komunikasi, 8(3).

Squire, C. (1989). Significant Differences Feminism in Psychology. London: Routledge.

Storey, J. (2004). Teori Budaya dan Budaya Pop: Memetakan Lanskap Konseptual Cultural Studies. Qalam. Yogyakarta.

Sudaryanto. (1993). Metode dan Aneka Teknik Analisis Bahasa. Duta Wacana University Press.

Sturken, M., \& Cartwright, L. (2009). Practices of Looking. New York: Oxford University Press.

Umarela, F. H., Dwityas, N. A., \& Zahra, D. R. (2020). Representasi Ideologi Supremasi Kulit Putih dalam Iklan Televisi, 4(1), 64-84. 